\title{
ANALISIS FAKTOR RISIKO TERJADINYA DIARE PADA BALITA DI WILAYAH KERJA PUSKESMAS PAKUAN BARU KOTA JAMBI
}

\author{
Nurul Fitriani, Armaidi Darmawan, Anggelia Puspasari \\ Fakultas Kedokteran dan IImu Kesehatan, Universitas Jambi, Jambi, \\ Corresponding author email: nurulfitriani1599@gmail.com
}

\begin{abstract}
:
Diarrheal is one of the main causes of the high morbidityand mortality rates for children worldwide. Identified risk factor of diarrhea provide better prevention and treatment strategy. The aims of this study was to determine the description and relationship of risk factors for exclusive breastfeeding, immunization status, age in children, gender in children, mother's hand washing habits, water sources, family latrines, mother's education level, mother's employment status, socioeconomic with the incidence of diarrhea in children under two in the Pakuan Baru Community Health Center Jambi City in 2020. The study design was case-control. This research held in Pakuan Baru Community Health Center Located in Jambi. This research periods was August-November 2020. One hundred of under two children participated in this study, 50 suffering diarrhea and 50 not suffering diarrhea. Interview with questioner was perform to asses risk factor of diarrhea. This study reported age 0-12 months, not having exclusive breast feeding, not having complete immunization, unproper hand washing technique, unproper water resources, low education level of mothers and low socio-economic increased risk of diarrhea in children under two. Dominant factor for risk of diarrhea were unproper hand washing technique and incomplete immunization.
\end{abstract}

Keywords : Diarrhea, risk factors, toddler 


\begin{abstract}
Abstrak:
Penyakit diare merupakan salah satu penyebab utama tingginya angka kesakitan dan kematian anak di dunia. Identifikasi faktor risiko diare selaras dengan strategi pencegajan dan tatalaksana diare yang lebih menyeluruh. Tujuan penelitian ini untuk mengetahui gambaran dan hubungan faktor resiko AS/ eksklusif, status imunisasi, usia pada anak, jenis kelamin pada anak, kebiasaan mencuci tangan pada ibu, sumber air, jambankeluarga, tingkat pendidikan ibu, status pekerjaan ibu, sosial ekonomi dengan kejadian diare pada balita di Wilayah Puskesmas Pakuan Baru Kota Jambi Tahun 2020. Penelitian merupakan penelitian kasus kontrol. Peneltian berlangsung di wilayah Puskesmas Pakuan Baru Kota Jambi, selama Agustus-November 2020. Sebanyak 100 balita dibawah dua tahun mengikuti penelitian ini, 50 orang merupakan balita diare dan 50 orang tidak menderita diare. Wawancara dengan ibu berdasarkan kuesioner dilakukan untuk pengambilan data risiko diare. Studi ini melaporkan menunjukkan balita usia 0-12 bulan, tidak mendapatkan ASI eksklusif, imunisasi yang tidak lengkap, kebiasaan mencuci tangan yang buruk, sumber air yang buruk, rendahnya tingkat pendidikan ibu dan sosial ekonomi yang rendah meningkatkan risiko balita mengalami diare. Faktor risiko paling dominan dari analisis multivariate adalah kebiasaan mencuci tangan yang buruk dan imunisasi yang tidak lengkap.
\end{abstract}

Kata Kunci : Diare , faktor risiko, balita

\section{PENDAHULUAN}

Diare adalah tidak normalnya pengeluaran feses yang ditandai dengan peningkatan volume dan keenceran feses serta, frekuensi buang air besar lebih dari 3 kali sehari. Pada umumnya, diare lebih dominan menyerang anak dengan usia dibawah 5 tahun atau balita karena, daya tahan tubuh balita yang cenderung masih dalam kategori lemah, sehingga balita sangat rentan terpapar penyebaran bakteri-bakteriyang menyebabkan diare. Pada kasus tertentu, jika diare disertai dengan terjadinya muntah berkelanjutan, maka akan menyebabkan dehidrasi. Inilah yang harus selalu diwaspadai karena sering terjadi keterlambatan dalam pertolongan dan mengakibatkan kematian. ${ }^{1}$
Penyakit diare hingga kini masih menjadi masalah global dengan derajat kesakitan dan kematian yang tinggi di berbagai negara terutama di negara berkembang, dan juga sebagai salah satu penyebab utama tingginya angka kesakitan dan kematian anak di dunia. WHO (World Health Organization, 2013) setiap tahunnya ada sekitar 1,7 miliar kasus diare dengan angka kematian 760.000 anak di bawah usia 5 tahun.2,3 Masalah diare di Indonesia sering terjadi dalam bentuk KLB. Cakupan perilaku kebersihan dan sanitasi yang rendah sering menjadi faktor risiko terjadinya $K L B$ diare. ${ }^{2}$ Pada tahun 2015 terjadi 18 kali KLB diare dengan jumlah penderita 1.213 orang dan kematian 30 orang dengan CFR sebanyak $2.47 \%$. Berdasarkan karakteristik penduduk, kelompok umur balita adalah kelompok yang paling tinggi menderita diare. Insiden diare balita di Indonesia adalah $6.7 \% .^{3}$ 


\section{METODE}

Penelitian ini penelitian analitik dengan pendekatan studi case control. Terdapat 100 sampel pada penelitian ini (50 diare dan 50 nondiare) yang datang berobat di Wilayah Puskesmas Pakuan Baru Kota Jambi. Kriteria inklusi pada penelitian ini yaitu untukkasus balita usia (0-5 tahun), balita penderita diare yang datang berobat ke Puskesmas Pakuan Baru. Untuk kontrol balita non diare dengan umur yang sama (0-5 tahun) , balita dengan jenis kelamin yang sama yang datang berobat dengan penyakit selain diareke Puskesmas Pakuan Baru. Kriteria Eksklusi untuk kasus balita dengan diare komplikasi berat yang datang berobat ke Puskesmas Pakuan Baru.. Analisis data pada penelitian ini yaitu analisis univariat, bivariat, dan multivariat.

\section{HASIL DAN PEMBAHASAN}

\section{Analisis Univariat}

Analisis univariat faktor risiko terjadinya diare ditampilkan pada tabel 1 . Presentase pemberian ASI eksklusif, kelengkapan imunisasi, ketersediaan sumber air baik dan jamban lebih tinggi pada kelompok yang tidak diare lebih besar dibandingkan kelompok diare, Presentase status sosial yang lebih tinggi juga dijumpai pada kelompok yang tidak diare (tabel 1).
Tabel 1. Analisis Univariat Faktor Risiko Diare

\begin{tabular}{llll}
\hline Variabel & Kasus & \multicolumn{2}{l}{ Kontrol } \\
\cline { 2 - 4 } & $\mathrm{N}=50$ & $\%$ & $\mathrm{~N}=50$
\end{tabular}

\begin{tabular}{lllll}
\hline \multicolumn{1}{l}{\begin{tabular}{l} 
Asi Eksklusif \\
\multicolumn{1}{c}{ Asi }
\end{tabular}} & 10 & 20 & 1 & 2,0 \\
\hline $\begin{array}{l}\text { Tidak Eksklusif } \\
\text { Asi Eksklusif }\end{array}$ & 40 & 80 & 49 & 98 \\
\hline $\begin{array}{l}\text { Imunisasi } \\
\text { Imunisasi }\end{array}$ & & & & \\
tidak lengkap & 7 & 14 & 0 & 0 \\
\hline $\begin{array}{l}\text { Imunisasi } \\
\text { lengkap }\end{array}$ & 43 & 86 & 50 & 100 \\
\hline
\end{tabular}

\begin{tabular}{lllll}
\hline \multicolumn{5}{l}{ Kebiasaan mencuci tangan pada ibu } \\
\hline Buruk & 11 & 22 & 0 & 0 \\
\hline Baik & 39 & 78 & 50 & 100
\end{tabular}

\begin{tabular}{lllll}
\hline $\begin{array}{l}\text { Sumber air } \\
\text { buruk }\end{array}$ & 10 & 20 & 1 & 2,0 \\
\hline baik & 40 & 80 & 49 & 98 \\
\hline Wc/jamban & & & & \\
\hline Tidak ada & 3 & 6,0 & 1 & 2,0 \\
\hline Ada & 47 & 94 & 49 & 98
\end{tabular}

\begin{tabular}{lllll}
\hline Pendidikan Ibu & & & & \\
\hline Tamat SD & 7 & 7 & 1 & 1 \\
\hline Tamat SMP & 16 & 16 & 18 & 18 \\
\hline Pekerjaan Ibu & & & & \\
\hline Tidak Bekerja & 39 & 78 & 37 & 74 \\
\hline Bekerja & 11 & 22 & 13 & 26 \\
\hline $\begin{array}{l}\text { Sosial } \\
\text { Ekonomi }\end{array}$ & & & & \\
\hline Rendah & 20 & 40 & 9 & 18 \\
\hline Tinggi & 30 & 60 & 41 & 82 \\
\hline Usia anak & & & & \\
\hline 0-12 bulan & 28 & 56 & 45 & 90 \\
\hline 13-24 bulan & 22 & 44 & 5 & 10 \\
\hline Jenis Kelamin & & & & \\
\hline Laki-Laki & 36 & 72 & 38 & 76 \\
\hline Perempuan & 14 & 28 & 12 & 24 \\
\hline
\end{tabular}




\section{Analisis Bivariate dan Multivariat}

Tampilan analisis biavariat faktor risiko diare dapat dillihat pada tabel 2 .

Tabel 2. Analisis bivariat faktor risiko diare

\begin{tabular}{llll}
\hline Variabel & OR & $95 \% \mathbf{C l}$ & Nilai p \\
\hline Asi eksklusif & 12,250 & $1,504-99,798$ & $0,004^{*}$ \\
\hline Kelengkapan & 2,163 & $1,737-2,693$ & $0,012^{*}$ \\
imunisasi & & & \\
\hline Kebiasaan & 2,282 & $1,804-2,887$ & $0,000^{*}$ \\
mencuci & & & \\
tangan & & & \\
\hline Kualitas & 0,082 & $0,010-0,665$ & $0,004^{*}$ \\
sumber air & & & \\
\hline Ketersediaan & 3,128 & $0,314-31,142$ & 0,617 \\
WC/jamban & & & \\
\hline Tingkat & 7,977 & $0,943-67,456$ & $0,030^{*}$ \\
pendidikan & & & \\
ibu & & & \\
\hline
\end{tabular}

\begin{tabular}{|c|c|c|c|}
\hline Pekerjaan ibu & 1,246 & $0,496-3,127$ & 0,640 \\
\hline $\begin{array}{l}\text { Status sosial } \\
\text { ekonomi }\end{array}$ & 3,037 & $1,214-7,597$ & $0,015^{*}$ \\
\hline
\end{tabular}

\begin{tabular}{lccc}
\hline Usia anak & 0,141 & $0,048-0,416$ & 0,000 * \\
\hline Jenis Kelamin & 0,812 & $0,332-1,989$ & 0,648
\end{tabular}

${ }^{*}$ nilai p signifikan $<0.05$.

Riwayat ASI tidak eksklusif, imunisasi tidak lengkap, kebiasaan mencuci tangan yang buruk, sumber air yang buruk, rendahnya tingkay pendidikan ibu dan status sosial ekonomi merupakan faktor risiko diare yang signifikan secara statistik. Sedangkan ketersediaan jamban dan pekerjaan ibu tidak bermakna sebagai faktor risiko diare (tabel 2).

Sebagai kelanjutan analisis biavariate dilakukan analisis multivariat menggunakan regresi logistic. Tampilan analisis univariat dapat dilihat pada tabel 3.

Tabel 3. Analisis multivariat faktor risiko diare (model akhir regresi logistic)

\begin{tabular}{llll}
\hline Variabel & $\operatorname{Exp}(\mathrm{B})$ & $\mathbf{9 5 \%} \mathbf{C l}$ & Nilai $\mathbf{p}$ \\
\hline $\begin{array}{l}\text { Kebiasaan } \\
\text { cuci tangan } \\
\text { pada ibu }\end{array}$ & 4,124 & $1,926-$ & $<\mathbf{0 . 0 0 1}$ \\
& & 8,833 & \\
\hline $\begin{array}{l}\text { Kelengkapan } \\
\text { imunisasi }\end{array}$ & 2,801 & $1,052-$ & 0,039 \\
& & 7,453 & \\
\hline
\end{tabular}

Analisis multivariat regresi logistic dilakukan dengan stepwise backward. Pada model akhir didapatkan faktor risiko yang bermakna dan saling mempengaruhi terhadap kejadian diare adalah kebiasaan mencuci tangan dan kelengkapan imuninasi. Kebiasaan mencuci tangan yang buruk meningkatkan faktor risiko kejadian diare sebanyak 4,124 kali lipat. Imunisasi yang tidak lengkap meningkatkan faktor risiko doare sebesar 2,801 kali (tabel 3).

\section{Hubungan asi eksklusif dengan kejadian diare pada balita}

Analisis bivariat menunjukkan terdapat hubungan bermakna antara asi eksklusif dengan kejadian diare. Masih rendahnya cakupan keberhasilan pemberian ASI eksklusif pada dipengaruhi oleh banyak faktor seperti banyaknya anggapan bahwa ASI saja tidak cukup untuk bayi sehingga bayi dianggapmembutuhkan makanan tambahan 
lainnya. Hasil penelitian ini sejalan dengan penelitian yang dilakukan oleh Maretha Anthya dkk (2016) di Wilayah Puskesmas Nanggalo Padang yang menyatakan bahwa terdapat hubungan antara pemberian asi eksklusif dengan kejadian diare pada balita, dengan nilai $p(0,029<0,05)$. Penelitian lain yang dilakukan oleh Wijayanti (2010) juga menyatakan bahwa ada hubungan yang signifikan antara pemberian ASI eksklusif dengan kejadian diare. Penelitian yang dilakukan oleh Gita Hamu (2015) juga menyatakan bahwa ada hubungan antara pemberian asi eksklusif dengan kejadian diare pada balita. Hal ini disebabkan balita yang diberikan ASI eksklusif memiliki resiko lebih rendah terkena infeksi gastrointestinal dibanding balita yang hanya mendapat ASI selama 3-4 bulan atau bahkan tidak mendapatkan ASI. ASI merupakan makanan yang ideal untuk bayi pada 6 bulan pertama kehidupan. ${ }^{4}$

\section{Hubungan status imunisasi dengan kejadian diare pada balita}

Hasil analisis Fisher's exact test diperoleh nilai pyaitu $0,012(p<0,05)$. Hal ini menunjukkan bahwa terdapat hubungan bermakna antara status imunisasi dengan kejadian diare pada balita di Wilayah Puskesmas Pakuan Baru Kota Jambi tahun 2020. Tujuan diberikan imunisasi adalah untuk membentuk kekebalan tubuh anak agar mampu melawan berbagai gangguan bakteri dan virus yang ada di sekeliling tempat hidupnya. Dengan imunisasi balitadapat menurunkan angka kesakitan terhadappenyakit spesifik hingga $80 \% .^{5}$ Hasil penelitian ini sejalan dengan penelitian Martini dan Kurniawati (2016) bahwa terdapat hubungan antara status imunisasi dengan kejadian diare pada balita. Nilai $p(0,016<0,05)$. Hal ini disebabkan karna dengan imunisasi, tubuh anak akan bereaksi dan antibodi meningkat untuk dapat melawanantigen yang masuk ke dalam tubuh. Pemberian imunisasi adalah salah satu tindakan pencegahan terjadinya diare. Tidak ada imunisasi khusus untuk permasalahan diare, tetapi pemberian imunisasi campak memberi efek samping mencegah diare. ${ }^{6}$

\section{Hubungan Usia Anak dengan Kejadian Diare Pada Balita}

Hasil analisis chi square test diperoleh nilai $p$ yaitu $0,000(p<0,05)$. Hal ini menunjukkan bahwa terdapat hubungan bermakna antara usia anak dengan kejadian diare pada balita di Wilayah Puskesmas Pakuan Baru Kota Jambi tahun 2020. Hasil penelitian ini sejalan dengan penelitian yang dilakukan oleh Herry Poernomo dkk (2016) di Wilayah Puskesmas Baamang Kabupaten Ketowaringin Timur yang menyatakan bahwa terdapat hubungan antara usia anak dengan kejadian diare pada balita, dengan nilai $p$ $(0,031<0,05)$. Hasil Penelitian lain yang dilakukan oleh Shintamurniwaty sejalan bahwa terdapat hubungan antara usia balita 
terhadap kejadian diare pada balita. Survei Demografi dan Kesehatan Indonesia (SDKI) tahun 1991 juga menemukan bahwa semakin muda usia anak balita semakin besar kecenderungan terkena penyakit diare.Faktor sosiodemografi lain yang dapat memengaruhi kejadian diare adalah usia. Tingginya angka diare pada anak balita yangberusia semakin muda dikarenaka semakin rendah usia anak balita daya tahan tubuhnyaterhadap infeksi penyakit terutama penyakit diare semakin rendah, lebih-lebih jika status gizinya kurang dan berada dalam lingkungan yang kurang memadai. ${ }^{6}$

\section{Hubungan Jenis Kelamin Anak dengan Kejadian Diare Pada Balita}

Hasil analisis chi square test diperoleh nilai $p$ yaitu $0,648(p>0,05)$. Hal ini menunjukkan bahwa tidak terdapat hubungan bermakna antara jenis kelamin anak dengan kejadian diare pada balita di Wilayah Puskesmas Pakuan Baru Kota Jambi tahun 2020. Hasil Penelitian ini sejalan dengan penelitian yang dilakukan oleh Jatmiko Aji di Rumah Sakit Islam Sultan Agung Semarang (2015) yang menyatakan bahwa tidak ada hubungan antara jenis kelamin anak dengan kejadian diare pada balita. Pada penelitian lain yang dilakukan oleh Debby (2019) didapatkan hasil $p$-value $=0,689$ yang berarti jenis kelamin tidak berhubungan dengan penyakit diare dalam 3 bulan terakhir. Hal ini sesuai dengan penelitian yang telah dilakukan oleh Mia Kartika pada tahun 2016 yang membuktikan bahwa tidak ada hubungan jenis kelamin dengan kejadian diare dengan $p$-value sebesar 0,38 . Hal ini dikarenakan Diare dapat menyerang siapa saja baik laki-laki maupun perempuan tergantung beberapa faktor seperti faktor gizi, faktor makanan, faktor sosial ekonomi, dan faktor lingkungan. ${ }^{7}$

\section{Hubungan Kebiasaan Mencuci Tangan Pada Ibu dengan Kejadian Diare pada balita}

Hasil analisis chi square test diperoleh nilai $p$ yaitu $0,000(p<0,05)$. Hal ini menunjukkan bahwa terdapat hubungan bermakna antara kebiasaan mencuci tangan pada ibu dengan kejadian diare pada balita di Wilayah Puskesmas Pakuan Baru Kota Jambi tahun 2020. Mencuci tangan dengan sabun mampu menghilangkan atau mengurangi mikroorganisme patogen pada tangan yang tidak bisa kita lihat secara kasatmata. Pada keadaan darurat biasanya sumber air bersih tidak bisa kita identifikasi bebas dari kontaminasi sehingga potensial terjadinya perpindahan bakteri patogen dari tangan, alat makan dan pengelolaan makanan meningkat. Cuci tangan merupakan hal yang mudah untuk dilakukandan memberi kontribusi pada peningkatan status kesehatan masyarakat namun masih sering disepelekan oleh masyarakat. Tangan yang tercemar akibat memegang sesuatu kemudian makan tanpa cuci tangan makapatogen ikut tertelan masuk kedalam tubuh. Cuci tangan baik sebelum mempersiapkan makan, setelah buang air besar dan sebelum menyuapi makan anak 
agar dapat meminimalisir kuman yang ada di tangan danmencegah berbagai penyakit dan tangan tetap bersih. Apabila perilaku ibu cuci tanganlebih di terapkan dalam keluarga akan sangat berdampak positif terhadap kesehatan. $^{8}$ Hasil penelitian ini sejalan dengan penelitian yang dilakukan oleh Yulianto Wijaya (2012) yang menyatakan bahwa terdapat hubunganPerilaku Ibu dalam Mencuci Tangan Pakai Sabun dengan Kejadian Diare pada Anak. Hal ini disebabkan karna kebiasaan mencuci tangan berpengaruh terhadap terjadinya diare pada balita. Kemungkinan hal ini disebabkan karena balita sangat rentan terhadap mikroorganisme dan berbagai ageninfeksius, segala aktivitas balita dibantu olehorang tua khususnya ibu, sehingga cuci tangan sangat diperlukan oleh seorang ibu sebelum dan sesudah kontak dengan bayi, yang bertujuan untuk menurunkan risiko terjadinya diare pada balita. Hal ini selaras dengan panduan Depkes RI (2011) yang menyatakan bahwa mencuci tangan yang baik dan benar dapat menurunkan angka kejadian diare sebesar $47 \% .^{9}$

\section{Hubungan Sumber Air dengan Kejadian Diare Pada Balita}

Hasil analisis chi square test diperoleh nilai $p$ yaitu $0,004(p<0,05)$. Hal ini menunjukkan bahwa terdapat hubungan bermakna antara sumber air dengan kejadian diare pada balita di Wilayah Puskesmas Pakuan Baru Kota Jambi tahun 2020. Tersedianya sumber air yang bersih merupakan salah satu upaya untuk memperbaiki derajat kesehatan. Kesehatan lingkungan meliputi penyehatan air, yakni pengamanan dan penetapan kualitas air untuk berbagai kebutuhan dan kehidupan manusia. Dengan demikian air yang dipergunakan untuk keperluan sehari-hari selain memenuhi atau mencakupi dalam kuantitas juga harus memenuhi kualitas yangtelah ditetapkan. Air dapat berperan sebagai transmisi penularan suatu penyakit melalui mikroorganisme yang ditularkan lewat jalur air (water borne disease) atau jalur peralatanyang di cuci dengan air (water washed disease). ${ }^{8}$ Hasil penelitian ini sejalan denganpenelitian yang dilakukan oleh I Made Subhawa Harsa (2019) Hubungan antara sumber air dengan kejadian diare menyatakan bahwa terdapat hubunganantara sumber air dengan kejadian diare. Hal ini disebabkan karna sebagian besar diare disebabkan oleh infeksi bakteri yang ditularkan melalui cara fecal-oral. ${ }^{8}$

\section{Hubungan Jamban/WC Keluarga dengan Kejadian Diare Pada Balita}

Hasil analisis Fisher's exact test diperoleh nilai $p$ yaitu $0,617(p>0,05)$. Hal ini menunjukkan bahwa tidak terdapat hubungan bermakna antara jenis jamban/wc keluarga dengan kejadian diare pada balita di Wilayah Puskesmas Pakuan Baru Kota Jambi tahun 2020. Pada penelitian ini lebih dari setengah responden mempunyai jamban danmemenuhi syarat, untuk jaman saat ini rata- rata semua rumah atau semua keluarga memilik wc/jamban dirumahnya yang memenuhi 
syarat. Jadi untuk keperluan BAB dan BAK menggunakan wc sehingga lingkungan tidak tercemar oleh tinja. Hasil penelitian ini tidak sejalan dengan penelitian yang dilakukan Saktha Yudha dkk (2019) yang menyatakan bahwa ada hubungan antara jamban keluarga dengan kejadian diare. Nilai $p(0,001)$. Karna pada penelitiannya menunjukkan lebih dari setengah responden yang tidak memiliki jamban terutama yang tidak memenuhi syarat. Dengan kondisi jamban keluargayang belum memenuhi syarat, dapat menyebabkan timbulnya kejadian diare pada balita yang disebabkan kotoran tinja yangtidak terkubur rapat akan mengundang lalat maupun tikus yang akan berdampak terhadap kesehatan lingkungan. ${ }^{9}$

\section{Hubungan Tingkat Pendidikan Ibu dengan Kejadian Diare Pada Balita}

Hasil analisis fisher's exact test diperoleh nilai $p$ yaitu $0,030(p<0,05)$. Hal ini menunjukkan bahwa terdapat hubungan bermakna antara tingkat pendidikan ibu dengan kejadian diare pada balita di Wilayah Puskesmas Pakuan Baru Kota Jambi tahun 2020. Jenjang pendidikan memegang peranan cukup penting dalam kesehatan suatu masyarakat. mempertimbangkan dan menganalisis akibat yang terjadi. ${ }^{10}$ Hasil penelitian ini sejalan dengan penelitian Hoirunisa Fathia dkk (2015) Hubungan tingkat pendidikan dan pengetahuan ibu dengan kejadian diare yang menyatakan bahwa terdapat hubungan antara tingkat pendidikan ibu dengan kejadian diare. Nilai $p(0,001) .{ }^{11}$ Pendidikan ibu yang rendah akan menjadikan mereka sulit untuk diberi tahu mengenai pentingnya kebersihan perorangan dan sanitasi lingkungan untuk mencegah terjangkitnya penyakit menular, termasuk diantaranya diare.

Dengan sulitnya mereka menerima penyuluhan, menyebabkan mereka tidak peduli terhadap upaya pencegahan penyakit menular. Ibu yang berpendidikan tinggi akan lebih cenderung menanamkan dan melaksanakan hidup sehat dari pendidikan yang di terimanya. Sedangkan yang berpendidikan rendah dalam pelaksanaan hidup sehathanya berdasarkan pengalaman yang di dapatnya tanpa mempertimbangkan dan menganalisis akibat yang terjadi. ${ }^{10}$

\section{Hubungan Status Pekerjaan Ibu dengan Kejadian Diare Pada Balita}

Hasil analisis chi square test diperoleh nilai $p$ yaitu $0,640(p>0,05)$. Hal ini menunjukkan bahwa tidak ada hubungan bermakna antara status pekerjaan ibu dengan kejadian diare pada balita di Wilayah Puskesmas Pakuan Baru Kota Jambi tahun 2020. Hasil penelitian ini sejalan dengan penelitian Yulianto Wijaya (2012) faktor resiko kejadian diare balita disekitar TPS banaran kampus Unnes yang menyatakan tidak ada hubungan antara status pekerjaan ibu dengan kejadian diare pada balita. Nilai $p(0,451)$. Ibu balita yang bekerja menyebabkan adanya aktivitas di luar rumah, sehingga kegiatan untuk mengasuh dan merawat balita menjadi 
terbatas. Pada ibu anak yeng terkena diare biasanya kurang cepat tertangani karena kesibukan dari pekerjaan ibu. Dimana penanganan anak yang terkena diare dikarenakan ketiadaan waktu untuk memeriksa ke tenaga kesehatan, hal ini terjadi karena kadang waktu yang bersamaan dengan waktu kerja yang tidak bisa ditinggalkan, yang akibatnya diare pada anak akan semakin kritis. Dibandingkan dengan ibu yang tidak bekerja akan lebih cepat dalam penangan diere pada anaknya karena banyaknya waktu yang digunakan dalam menangani anaknya. ${ }^{12}$

\section{Hubungan Sosial Ekonomi dengan Kejadian Diare Pada Balita}

Hasil analisis chi square test diperoleh nilai $p$ yaitu $0,015(p<0,05)$. Hal ini menunjukkan bahwa terdapat hubungan bermakna antara sosial ekonomi keluarga dengan kejadian diare pada balita di Wilayah Puskesmas Pakuan Baru Kota Jambi tahun 2020. Penghasilan keluarga menunjukan adanya hubungan dengan kejadian diare jika penghasilan meningkat maka yang dibeli bisa bervariasi, mereka yang berpendapatan rendah memiliki keterbatasan dalam usaha pencegahan penyakit dan pemanfaatan sarana kesehatan. Keadaan ekonomi rendah menunjukkan status gizi yang kurang. Hasil Penelitian ini sejalan dengan penelitian Rahmawati (2009) yang menyimpulkanbahwa terdapat hubungan sosial ekonomi dengan kejadian diare. Hasil penelitian ini juga sejalan dengan penelitian Rita Ariesta dkk (2013)
Hubungan sosial ekonomi keluarga dan pekerjaan ibu dengan kejadian diare pada balita menyatakan bahwa terdapat hubungan antara sosial ekonomi dengan kejadian diare pada balita. Nilai $p 0,006)$. Hal ini disebabkan karena diare lebihsering muncul pada bayi dan balita yang status ekonomi keluarganya rendah. Keluarga yang berpendapatan rendah memiliki keterbatasan dalam usaha pencegahan penyakit. Apabila tingkat pendapatan baik, maka fasilitas kesehatan mereka khususnya di dalam rumahnya akan terjamin, masalahnya dalam penyediaan air bersih, penyediaan jamban sendiri atau jika mempunyai ternak akan diberikan kandang yang baik dan terjaga kebersihannya. ${ }^{9}$

\section{Faktor yang Paling Dominan}

Berdasarkan hasil analisis multivariat faktor yang paling dominan yang pertama adalah kebiasaan mencuci tangan pada ibu. Hasil analisis multivariat ini sejalan dengan penelitian yang dilakukan oleh rahmiliya (2014) yaitu hasil dari uji chi squarediketahui terdapat 3 variabel yang diujiregresi logistic yaitu PHBS, hiegine sanitasi makanan, status gizi. Hasil analisis uji regresi pada model terakhir terdapat 2 variabel yang paling dominan salah satunya adalah PHBS dengan nilai sig $<0,05$ sehingga variabel PHBS yang menjadi prediktor utama dalam penelitian tersebut. ${ }^{13}$ Berdasarkan hasil analisis multivariat faktor yang paling dominan yang kedua adalah imunisasi. Imunisasi dapat menjadi salah satu tindakan untuk pencegahan diare. Dengan pemberian 
imunisasi tubuh anak akan bereaksi dan antibodi meningkat sehingga dapat melawan antigen yang masuk kedalam tubuh. Tidak ada imunisasi khusus untuk permasalahan diare, tetapi pemberian imunisasi campak memberi efek samping mencegah diare. ${ }^{14}$

\section{KESIMPULAN}

Tidak terdapat hubungan antara jenis kelamin anak, wc/jamban, pekerjaan ibu dengan kejadian diare pada balita di wilayah Puskesmas Pakuan Baru Kota Jambi tahun
2020. Terdapat hubungan antara asi eksklusif, imunisasi, usia anak, kebiasaan mencuci tangan pada ibu, sumber air, pendidikan ibu, sosial ekonomi dengan kejadian diare pada balita di wilayah Puskesmas Pakuan Baru Kota Jambi tahun 2020. Faktor resiko yang paling dominan menentukan kejadian diare pada balita adalah kebiasaan mencuci tangan pada ibu dan imunisasi.

\section{DAFTAR PUSTAKA}

1. Maidarti dan Rima Dewi. Faktor-Faktor Yang Berhubungan Dengan Kejadian Diare Pada Balita ( Studi Kasus: Puskesmas Babakansari ). J Keperawatan. 2017;V(2):110-20.

2. Hartati S, Nurazila N. Faktor Yang Mempengaruhi Kejadian Diare Pada Balita Di Wilayah Kerja Puskesmas Rejosari Pekanbaru. J Endur. 2018;3(2):400.

3. Badan Penelitian dan Pengembangan Kesehatan. Riset Kesehatan Dasar (Riskesdas) 2013. Lap Nas2013.

4. Syah LP, Ardiansyah NY, Teguh R. Hubungan sanitasi lingkungan dengan kejadian diare pada balita diwilayah kerja puskesmas lainea kabupaten konawe selatan tahun 2017. Jimkesmas. 2017;2(7):111.

5. 5.Sukard dkk. Faktor yang Berhubungan dengan Kejadian Diare Pada Balita di Wilayah Kerja Puskesmas Poasia. Fakultas Kesmas. 2016;1-12.

6. Poernomo H, Setiawati M, Hadisaputro S, Budhi K, Adi MS. Faktor Risiko Kejadian Diare Akut pada Anak Balita (Studi Epidemiologis di Puskesmas Baamang Unit I Kabupaten Kotawaringin Timur). J Epidemiol Kesehat Komunitas [Internet]. 2016;1(2):77-82.Availablefrom: https://ejournal2.undip.ac.id/index.php/jekk/article/view/3946

7. Prawati DD. Faktor Yang Mempengaruhi Kejadian Diare Di Tambak Sari, Kota Surabaya. J PROMKES. 2019;7(1):34

8. Hendrastuti CB. Hubungan Tindakan Pencegahan lbu dengan Kejadian Diare pada Balita. J PROMKES.2019;7(2):215

9. Riyanto E, Adifa RFN. Hubungan Tingkat Pengetahuan, Pendidikan, Dan Pola Hidup Bersih Dan Sehat lbu Terhadap Kejadian Diare Pada Balita Di Puskesmas Sitopeng Kota Cirebon. J Kedokt Kesehat. 2016;3(4):1-8.

10. Harsa made subhawa. Hubungan Antara Sumber Air Dengan Kejadian Diare Padawarga Kampung Baru Ngagelrejo Wonokromo Surabaya The Relationship Between Clean Water Sources And The Incidence Of Diarrhea In Kampung Baru Resident At Ngagelrejo Wonokromo Surabaya. Sosial/Politik. 2019;5(3):1-6

11. Utama SYA, Inayati A, Sugiarto S. Hubungan Kondisi Jamban Keluarga Dan Sarana Air Bersih Dengan Kejadian Diare Pada Balita Di Wilayah Kerja Puskesmas Arosbaya Bangkalan. Din Kesehat J KebidananDan Keperawatan. 2019;10(2):820-32.

12. Winanti IL. Faktor Yang Berhubungan Dengan Kejadian Diare Pada Anak SDN Brujul Di KecamataN 
Jaten Kabupaten Karanganyar Tahun 2015. 2016;87.

13. Hendrastuti CB. Hubungan Tindakan Pencegahan Ibu dengan Kejadian Diare pada Balita. J promkes. 2019;7(2):215.

14. Rahmiliya. Faktor yang Mempengaruhi Kejadian Diare Di Puskesmas Kedungmundu Kota Semarang. Universitas Muhammadiyah Semarang. 2014. 